\author{
(online) $=$ ISSN $2285-3642$ \\ ISSN-L = $2285-3642$ \\ Journal of Economic Development, Environment and People \\ Volume 2, Issue 1, 2013 \\ URL: http://iedep.spiruharet.ro \\ e-mail: office jedep@spiruharet.ro
}

\title{
Environmental sustainability model and biodiversity preservation in Central Rhodopes
}

\author{
Zlatka Grigorova, Ekaterina Arabska* \\ University of Agribusiness and Rural Development - Bulgaria \\ *Corresponding author: katya arabska@abv.bg
}

\begin{abstract}
The paper examines the significance, opportunities and ways of biodiversity preservation and sustainable use of natural resources in the central region of the mountain of Rhodopes in Bulgaria.

The proposed integrated model of recommendations embraces the following issues: preservation of rare, in danger of extinction and protected plant and animal species and their habitats; implementation of approved environmentally friendly practices in plant growing and animal husbandry; sustainable use of forest, hunting and fishing resources; knowledge, capacity building and motivation in applying measures for sustainable development.

In fact that model is composed of many components and considers a number of important aspects. Its application will contribute to the sustainable use of natural resources and preserved biodiversity for future generations.
\end{abstract}

Keywords: environment, sustainability, biodiversity, sustainable development, habitats, rare and protected species

JEL Codes: Q00, Q01, Q18, Q20, Q28

\section{Introduction}

Although Bulgaria is a relatively small country $(110,912 \mathrm{sq} . \mathrm{km})$, it is rich in biological diversity due to it is highly varied climatic, geological, topographic and hydrologic conditions. These characteristics predetermine the occurrence of biota, consisting of 94 species of mammals, 383 birds, 36 reptiles, 16 amphibians, 207 Black Sea and freshwater fish, around 27,000 insects and other invertebrates, between 3,500 and 3,750 higher plant species and more than 6,500 lower plants and fungi. Thus Bulgaria countryregion ranks among the countries of the greatest biological diversity in Europe [11].

Bulgaria has some of the largest Natura 2000 areas in Europe covering $34.3 \%$ of its territory (Fig. 1). 


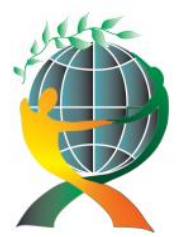

\author{
(online) $=$ ISSN $2285-3642$ \\ ISSN-L = $2285-3642$ \\ Journal of Economic Development, Environment and People \\ Volume 2, Issue 1, 2013
}

URL: http://jedep.spiruharet.ro

e-mail: office jedep@spiruharet.ro

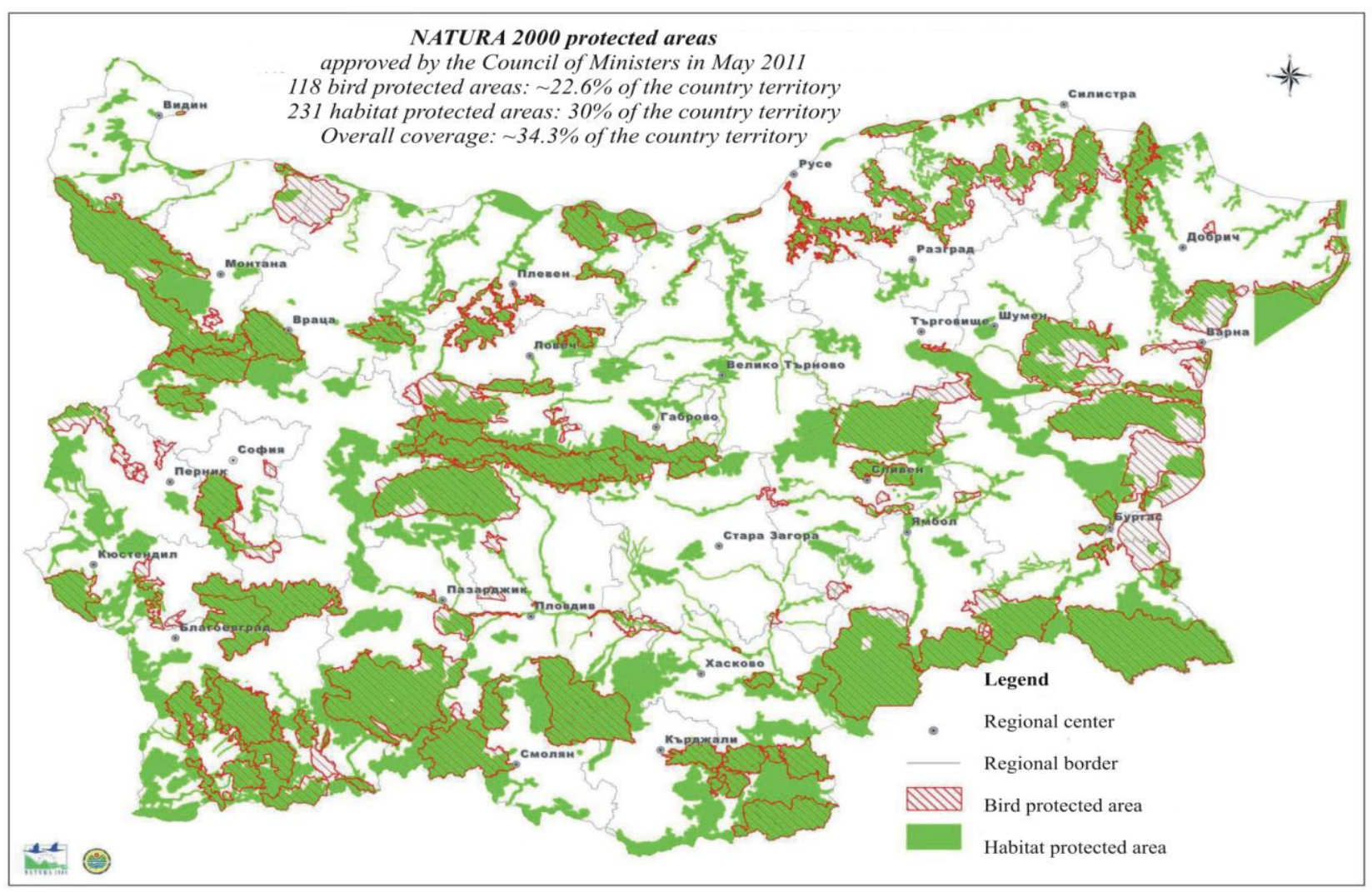

Fig. 1: Protected areas under Natura 2000 approved by the Council of Ministers in 2011

A variety of landscapes, geology and microclimates and thousands of years of human activity have resulted in a rich diversity of species, communities and natural habitats. Bulgaria contains three biogeographic areas (Alpine, Black Sea and Continental), a variety of communities and ecosystems and almost all major European habitat types [4].

Being a common European network composed of protected areas, Natura 2000 aims at providing long-term surviving of the most valuable and endangered species and habitats in Europe in accordance to the international agreements in the field of environmental protection and biodiversity preservation.

As an EU member state Bulgaria must comply with all relevant European Union legislation and directives, including the EU Directive 92/43 on the conservation of natural habitats and of wild fauna and flora and the EU Directive 79/409 on the conservation of wild birds [12].

The main requirements of the above stated directives are put in Bulgarian legislation through the Biodiversity Act of the Republic of Bulgaria adopted in 2011. The protected areas have been announced as a part of national ecological network. Those are pieces of land or water which are in compliance to the requirements for availability of plant and animal species of importance to biological diversity, as well as natural habitats according to the corresponding directive. 


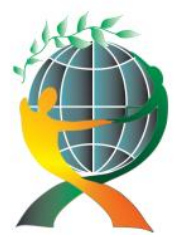

\author{
(online) $=$ ISSN $2285-3642$ \\ ISSN-L = $2285-3642$ \\ Journal of Economic Development, Environment and People \\ Volume 2, Issue 1, 2013 \\ URL: http://jedep.spiruharet.ro \\ e-mail: office jedep@spiruharet.ro
}

This paper examines the significance and the ways of biodiversity and landscape preservation in connection to the sustainability aspects in the Central Rhodopes Mountain in Bulgaria as a part of a mountain chain with exceptional ecological significance. Enormous climatic and soil variety in the region examined determines the great plant diversity and occurrence of Balkan endemic plants in danger of extinction. In the region some of the least damaged natural ecosystems are situated giving shelter of many rare animal species. Thanks to the fact that it has not been affected by the glaciers, many plant and animal species from Central and North Europe have found protection there [14]. Thus the Rhodope massive represents a valuable ecosystem on the Balkans and one of the most interesting regions in the whole Europe.

All this underlines the importance of biodiversity preservation in the region in terms of species diversity, genetic differences and variety of ecosystems. It is the combination of life forms and their interactions with each other and with the rest of the environment that has made Earth a uniquely habitable place for humans. Biodiversity provides a large number of goods and services that sustain our lives [1].

Thus the paper considers the goal of sustainable development to satisfy current needs but preventing and saving natural resources for future. Economic effectiveness, social responsibility and ecological conformability are the three pillars when characterizing sustainable development and those are implemented in the proposed model.

\title{
2. Materials and Methods
}

The recommendations proposed in this paper were formulated through an investigation of the biodiversity of the region and of the European and national legislative and strategic documents. In addition observations were made on place, local community was contacted and some good practices were looked for. On that basis the most important issues and key points were determined and conclusions were made.

\section{Results and Discussion}

In accordance to the Birds Directive in the region of Smolyan (which is the object of current investigation) 3 protected areas have been established: Trigrad-Mursalitsa, Persenk and Dobrostan, and according to the Habitats Directive: Western Rhodopes, Central Rhodopes and Tzigansko gradishte. The territories of Trigrad-Mursalitsa and Western Rhodopes overlay each other and Mursalitsa Hill is placed on the territory of both.

Trigrad-Mursalitsa is a territory of middle and high mountains. Forest, rock, meadow and pasture habitats are mainly presented there. Forests cover about 70\%, coniferous being the main part - spruce (Picea excelsa); pine spruce (Abies alba) and pine-tree (Pinus). Very small is the share of broad-leaved 


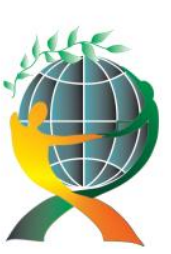

\author{
(online) $=$ ISSN $2285-3642$ \\ ISSN-L = $2285-3642$ \\ Journal of Economic Development, Environment and People \\ Volume 2, Issue 1, 2013 \\ URL: http://jedep.spiruharet.ro \\ e-mail: office jedep@spiruharet.ro
}

species beech-tree (Fagus) and mixed forests. There are two gorges with broad rock complexes (Trigrad and Buynovo). $74 \%$ of the land is owned by the state, the municipal property is $12 \%$, and private $-14 \%$ which gives lots of opportunities for implementation of the special measures proposed in the paper.

The preservation objectives:

- preservation and maintenance of endangered birds habitats in the periods of nesting and migration;

- improvement of nesting conditions for Falco naumanni and recovering its population in the region;

- recovering natural forest and pasture habitats;

- preservation of other bird species habitats endangered in Europe according to the Bern Convention on the Conservation of European Wildlife and Natural Habitats;

- investigation of the state of populations of nesting birds in the Annex 2 of Biodiversity Act of the Republic of Bulgaria for improving the conditions of maintaining their vitality and favorable nature conservation status;

- providing protection of vulnerable places of key importance for the species being objects of preservation;

- preserving and maintaining biological diversity in the region as a prerequisite of the stability of ecosystems;

- environmentally friendly use of natural resources and sustainable development of communities.

Objects of preservation: 141 species nesting birds, 68 of them being endangered or vulnerable, and special measures that are required for their habitats preservation. 20 species are described in the Red Book of Bulgaria.

Species of European Conservation Concern (SPECS) - 55, SPEC1 - 3 (Crex crex, Falco cherrug, Falco naumanni), SPEC2 - 16, SPEC3 - 20 species. The rest of the species are with a favourable nature conservation status but they are concentrated in Europe and their preservation is of special importance too.

The region provides suitable habitats for 37 species from Annex 2 of Biodiversity Act of the Republic of Bulgaria which requires special measures of protection. 29 of them are placed in Annex 1 of Directive $79 / 409$.

Objects of protection on the territory are the following bird species: Ciconia nigra, Pernis apivorus, Milvus migrans, Circaetus gallicus, Aquila pomarina, Aquila chrysaetos, Buteo ryfinus, Falco peregrinus, Alectoris graeca, Bonasa bonasia, Tetrao urogallus, Bubo bubo, Glaucidium passerinum, Aegolius funereus, Caprimulgus europaeus, alcedo attis, Picus canus, Dryocopus martius, Dendrocopos medius, Picoides tridactylus, Dendrocopos syriacus, Lullula arborea, Lanius collurio, Lanius minor, Sylvia nisoria, Emberiza hortulana. The territory is one of the most important places in Europe for preservation of valuable populations of Regulus regulus.

In the borders of the protected area the following activities have been forbidden: 


\author{
(online) $=$ ISSN $2285-3642$ \\ ISSN-L = $2285-3642$ \\ Journal of Economic Development, Environment and People \\ Volume 2, Issue 1, 2013 \\ URL: $\underline{\text { http://jedep.spiruharet.ro }}$ \\ e-mail: office jedep@spiruharet.ro
}

- ploughing up the pastures and their turning into arable land;

- pesticides use in pastures and meadows;

- mowing meadows before 1st July as well as mowing from the periphery towards the center;

- establishing new ballast mining places in river beds and terraces, water-power electricity works and wind generators with small exceptions if they are in accordance to the law.

Western Rhodopes is the biggest protected area in Bulgaria. It embraces 271909,21 ha.

Objectives of preservation:

- preservation of natural habitats and the habitats of species and their populations;

- preservation of natural status of natural and species habitats, including natural species composition, typical species and environmental conditions;

- recovering (when needed) the area and the natural status of natural and species habitats of priority as well as the species' populations being objects of preservation in the borders of the protected area.

The application of the proposed integrated model is needed because of several reasons:

- There is a serious and crescent problem connected to pasture habitats preservation and recovery and related to that traditional animal breeding in the region of the Rhodopes Mountain in Bulgaria;

- Pasture and meadow habitats of European significance are a subject of degradation in a great extend because of the insufficient number or the full absences of pasture animals. Those specific ecosystems depend strongly on herbivorous animals and mowing regimes;

- The populations of some rare species, very often objects of poacher's hunting, are in danger of extinction - for example Bonasa bonasia and Tetrao urogallus;

- The populations of some ecosystems structure defining species are significantly reduced as those of wild rabbit Lepus europaeus;

- The capacity and the motivation of agricultural producers and forests owners, hunters, fishermen, specialists and local community in doing high value agricultural lands management and activities in the framework of Natura 2000 is insufficient as is the case for the benefits of multifunctional planning and forest management, ways of wild flora and fauna habitats preservation and of species of European and world significance, etc.;

- There is a lack of a unified policy and a strategy of integration of forest managing and hunting practices with the measures of biodiversity preservation and natural resources integrated management; 


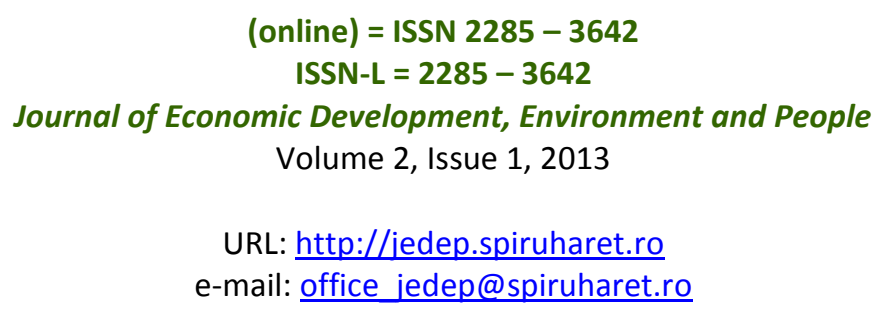

The typical sector approach is still being applied in the practices of forest management which hides some risks of a decrease in biodiversity (rare species and their habitats) in the near future.

In addition to the rules of Good agricultural practice adopted by the government, other law acts and strategic documents, investigations in the region led to the formulation of the following recommendations for biodiversity preservation and sustainable use of natural resources on the territory of the Central Rhodopes (Mursalitsa Hill) (Fig. 2).

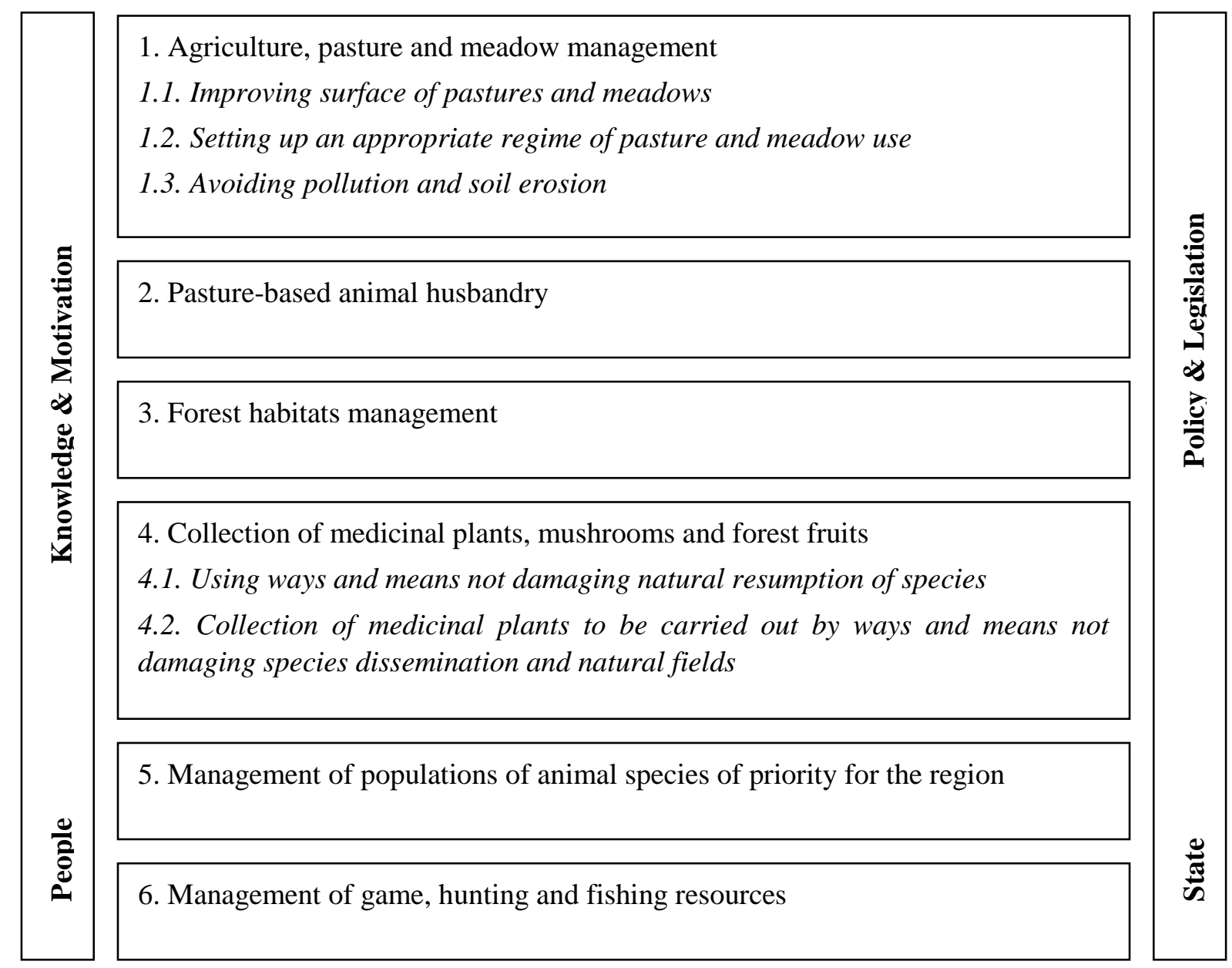

Fig. 2. Integrated model embracing the key issues in biodiversity preservation and sustainable development of Central Rhodopes - Mursalitsa Hill 


\author{
(online) $=$ ISSN $2285-3642$ \\ ISSN-L = 2285 - 3642 \\ Journal of Economic Development, Environment and People \\ Volume 2, Issue 1, 2013 \\ URL: http://jedep.spiruharet.ro \\ e-mail: office jedep@spiruharet.ro
}

\title{
4. Recommendations in the integrated model of biodiversity preservation and sustainable development of Central Rhodopes - Mursalitsa Hill
}

\subsection{Agriculture, pasture and meadow management}

In pasture and meadow management the following issues should be considered:

- pasture and meadow use that allows long-term preservation of biodiversity;

- the regime of use to be consistent with the climate and the soils in the region;

- the animal load of every one pasture to be in accordance to its productivity, pasture duration and day ratio which is dependent on the animals in agriculture - cows, sheep, horses, goats, etc.;

- the animal load to be mainly determined by the number which could be fed from a unit of area for a season.

\subsubsection{Improving surface of pastures and meadows}

- mechanical cleaning of bushes but in accordance with the objectives of the protected area avoiding the mass cutting of bushes, with an exception to juniper in cases of mass invasion in pastures and meadows;

- sufficient animal load of pastures;

- the control of weed and ruderal plant species to be executed by a control of the number of the animals, pasture prohibition early in the spring and in the late autumn and pasture on dry soil;

- sanitary mowing (1-2) for removing unwanted species (Veratrum album, prickles, Conium maculatum and others);

- adhering to the periods and the number of mowing (traditionally once in August);

- a combined use of mowing and pasture or mowing twice - regularly in a period of 2 years;

- cleaning of stones and concentrating them in dividing borders;

- observation of the European and national law;

- the regulation of water regime in wet habitats (pasture and meadows) to avoid the drainage methods;

- using natural fertilizer, manure;

- sowing suitable species on areas of strong degradation and erosion - the choice of the species must take into consideration the natural type of the territory and main fodder plants.

\subsubsection{Setting up an appropriate regime of pasture and meadow use}

- considering carefully the beginning and the end of the pasture season with the concrete characteristics of the region; 


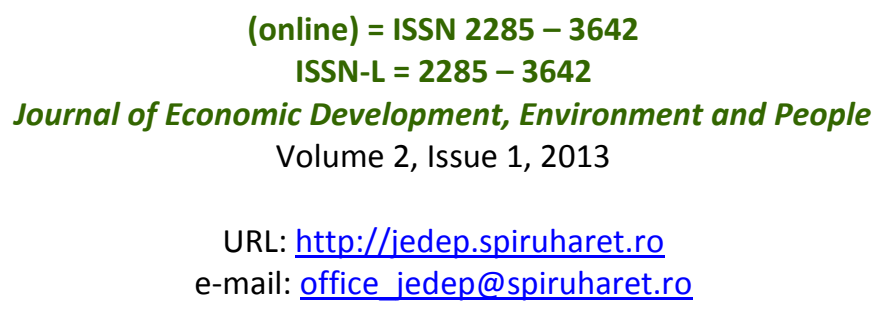

- providing an order in pasture - in spring to start from the lowest parts and gradually to move up, in autumn - in reverse order;

- introducing the rotation use of pastures - steep pastures where the turf is small to be used through the year in order to restore the natural turf;

- pasturing mainly in places which are strongly bushed, especially in the beginning of the vegetation;

- avoiding animal collection on a place in order to prevent the selective eating up;

- when needed, especially in cases of significant increase of the number of the animals, to implement a system for consecutive pasture though plotting the territory.

\subsubsection{Avoiding pollution and soil erosion}

- avoiding ploughing of tilted grounds on the tilt;

- in crops fertilization, especially for potatoes, besides manure and nitrogen to use potassium and phosphorus fertilizers;

- controlling the use of chemicals for plant protection - expiration dates and periods of quarantine;

- in farms, in dependence of the number of animals, to build works for manure storage with solid concrete basis in order to protect underground and surface water and soils of nitrates contamination;

- reducing to maximum pesticides use in pastures and meadows.

The management of pastures and meadows in a proper way can assure maximum produce and effectiveness in a farm.

\subsection{Pasture-based animal husbandry}

4.2.1. Recommendations for preservation and development of traditional pasture-based animal husbandry:

- undertaking preventive measures for avoiding damages of bears, strolling dogs, wolves, etc. through building up fences and protection of herds by dogs;

- obligatory registration of animals in farms and bee hives for making easier the application of compensation mechanisms in cases of damages and avoiding diseases advent;

- preservation of local varieties through the selection methods - supportive breeding;

- elaborating plans for local varieties and maintaining the genetic diversity;

- storage of spermatic fluid and embryos aiming at using the time trend and increase the population divergence;

- consolidating and creating professional farms;

- building up local processing works; 


\author{
(online) $=$ ISSN $2285-3642$ \\ ISSN-L = 2285 - 3642 \\ Journal of Economic Development, Environment and People \\ Volume 2, Issue 1, 2013 \\ URL: http://jedep.spiruharet.ro \\ e-mail: office jedep@spiruharet.ro
}

- increasing motivation, qualification and entrepreneurship of agricultural producers in fields of effective use of arable land, pastures, meadows, forests, crops and animals of different species by informational sessions, special training programs, courses, etc.

- improving subsidizing in the sector.

\title{
4.3. Recommendations for forest habitats management
}

- preservation of existing forest habitats by improvement in security guard - increasing the number of sections under guard and number of guards; increase in community engagement and intolerance towards the violations in the forests;

- fire-precaution measures - increasing and maintaining crop borders and mineralization bands, increasing the number of fire observers, building up permanent observation points and new antifire sheds, putting warning signs at the places of tourists collection (parking places, roads running though the forests, etc.), establishing suitable plain terrains for landing helicopters.

- elaborating and implementing a plan for multifunctional forest management including the benefits of hay collection for winter for feeding wild animals, developing the basis of the organized collection of herbs and forest fruits, mushrooms, Christmas trees, spruce barks, lightwood, etc.;

- setting felling with prolonged restoration period, leaving old and hollow trees, as well as fallen dry forest material spread up unevenly on the territory;

- preserving and controlling the mixed character of the plants;

- afforesting with typical local species and forest fruits trees;

- avoiding development of erosion processes - for example by building barrages and fortifications;

- providing preservation of the key elements of biodiversity in marking and taking out the felling leaving in the forest parts of dead wood with a different grade of degradation, as well as dead trees, etc.;

- preserving the so called 'old age islands' - old growth forests;

- preserving the big trees and those that have a diameter close to the maximal values for the concrete species, trees having a diameter of $100 \mathrm{~cm}$ and $1.3 \mathrm{~m}$ high because the big crowns are used as a shelter and a nesting place by birds;

- preserving the trees having nests of predatory birds because they have been used for many years by them;

- preserving the trees used by the cock of the wood Tetrao urogallus;

- providing zones of calmness. 


$$
\begin{gathered}
\text { (online) }=\text { ISSN } 2285-3642 \\
\text { ISSN-L = 2285 - 3642 }
\end{gathered}
$$

\subsection{Collection of medicinal plants, mushrooms and forest fruits}

\subsubsection{Using ways and means not damaging natural resumption of species}

- avoiding picking up of the whole mushroom - leaving the mycelium;

- in transportation using baskets - not polythene bags which do not allow spores dissemination;

4.4.2. Collection of medicinal plants to be carried out by ways and means not damaging species dissemination and natural fields

- avoiding collection before seed formation or picking up unripe fruits - it's a waste of resources;

- avoiding breakages of branches from the tops of trees and bushes;

- using scissors or a sickle when cutting the stalks in order to prevent the eradication;

- avoiding trampling down the fields or their pollution.

In the examined area Sideritis scardica is traditionally collected in great quantities. It is sold around the tourist objects which lead to the progressive decrease in natural populations. In that connection we give the following recommendations:

- cultivating the crop, especially around the tourist destinations places;

- temporary law restriction until restoration of its natural habitats;

- prohibiting the trade with non-cultivated plants and a stronger control by the authorized institutions.

\subsection{Population management of animal species of priority for the region}

\subsubsection{Ursus arctos}

- afforesting with forest fruits trees (plum, pear, apple, etc.) diffusely all over the region and around used agricultural lands;

- creating and maintaining fields with oats which is the main food during the spring period for waken up bears - the distance should be more than 1 kilometer from farms and buildings;

- electric fences for protection of domestic animals, beehives and agricultural crops;

- guard dogs for herds' protection;

- monitoring of the species with the objective of making assessments of number and trends;

- forming an emergency group in cases of rising problem animals - identification, chasing away, stamping and as an extreme measure shooting;

- popularizing the good practices in joint living bear-man;

- promoting new tourist services - places for observing the bear. 


\author{
(online) $=$ ISSN $2285-3642$ \\ ISSN-L = $2285-3642$ \\ Journal of Economic Development, Environment and People \\ Volume 2, Issue 1, 2013 \\ URL: http://jedep.spiruharet.ro \\ e-mail: office jedep@spiruharet.ro
}

\title{
4.5.2. Rupikapra rupikapra balkanika
}

- decreasing the number of strolling dogs;

- forming a special guard for the species;

- establishing a stronger control in order to avoid the poaching;

\subsubsection{Birds}

- postpone the mowing for the maximum latest period around the end of summer (in August when the nesting is finished) in cases of birds nesting on the land;

- leaving old and hollow tress;

- afforesting with forest fruits trees and avoiding their felling;

- avoiding ploughing up of pastures and meadows and their turning into arable lands;

- building and construction activities to be done only following the generative period of the birds (April-June).

\subsection{Recommendations for the management of game, hunting and fishing resources}

- applying methods of selective shooting;

- avoiding inbreeding by introduction of geographically remote populations;

- maintaining suitable density of predatory species;

- strong control of poaching;

- increasing the discipline and control during hunting;

- placing photo traps for observations and counting;

- creating conditions for feeding all over the year, feeding up and watering places;

- placing feeding-through for rare and endangered of extinction species;

- financing of the hunting associations for building facilities for game feeding;

- establishing new fodder fields for the game;

- limiting in hunting of some species in cases of decrease in the number of their populations;

- establishing of zones of calmness during the generative period;

- spreading the local Salmo trutta fario in natural water basins (not its competitor Oncorhynchus mykiss);

- gradual change of fish passes in established facilities (electricity works, water storage, etc.) with new ones;

- building fish passes in the river of Muglenska; 


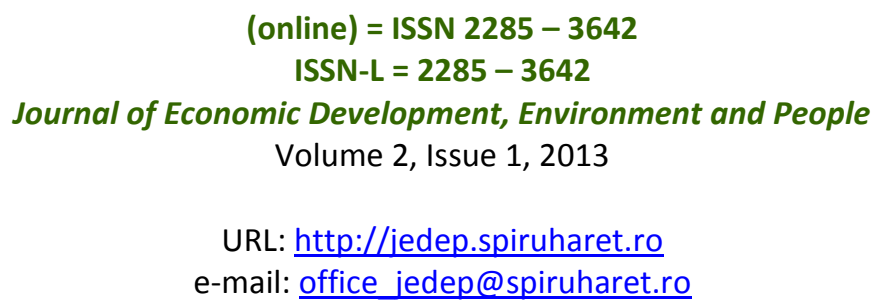

- preserving the population of Astacus astacus;

- establishing a stronger control system for permissions of usage of water and water facilities in the region;

- increasing control in giving permissions for economic activities in the region.

In general, in the region a special system of monitoring is needed embracing:

- invasion of bush and forest species;

- populations of Ursus arctos, Rupikapra rupikapra balkanika, Tetrao urogallus and other rare, in danger of extinction and protected species;

- identification and preservation of sustaining trees;

- building and construction activities, etc.

In order all of these to be implemented successfully there is a need of assuring the mass participation of the local community, state and municipal authorities, nongovernmental organizations, associations, training institutions and others involved in activities in the region.

\section{Conclusion}

The goal of the proposed recommendations implemented in an integrated model is finding the best ways of supporting sustainable management of natural resources and decreasing human impact on biodiversity in the region examined. They are directed towards the local community which plays a crucial role, as well as towards the authorized institutions, specialists, etc. They are in accordance to strategic documents on both national and local level, especially in the sections concerning environment and biodiversity.

The main conclusion which implements the most important recommendation is that special measures should be undertaken increasing the level of motivation, knowledge and entrepreneurship behaviour of the people in the region to use the rich natural resources, and especially the opportunity of the great biodiversity in the region, in environmentally friendly activities, particularly organic farming and alternative forms of tourism, in order to reach environment, social and economic sustainable development.

\section{References}

[1] Bulgarian Biodiversity Portal http://chm.moew.government.bg/

[2] Environmental Protection Act of the Republic of Bulgaria

[3] European Commission - Environment - Nature and Biodiversity http://ec.europa.eu/environment/nature/index_en.htm 


\author{
(online) $=$ ISSN $2285-3642$ \\ ISSN-L = $2285-3642$ \\ Journal of Economic Development, Environment and People \\ Volume 2, Issue 1, 2013 \\ URL: http://jedep.spiruharet.ro \\ e-mail: office jedep@spiruharet.ro
}

[4] European Environment Agency: Nature protection and biodiversity (Bulgaria)

http://www.eea.europa.eu/soer/countries/bg/soertopic_view?topic=biodiversity

[5] Grigorova Zl. 2011. Opportunities for mountain organic farming in protected areas according to Natura 2000 of Mursalitsa Hill. New knowledge Journal of Science \#3, pp. 64-76

[6] Ivanova M., Zl. Grigorova, M. kechev, Iv. Shopova Biological and landscape diversity as a basis for development of specialized forms of ecotourism. 2012. CCEDEP II. International scientific conference Climate change, economic development, environment and people, Presov 2012, pp. 163-170

[7] Medicinal Plants Act of the Republic of Bulgaria

[8] Ministry of Environment and Water in Bulgaria http://www3.moew.government.bg/

[9] National Environmental Strategy and Action Plan

[10] National Plan for Biodiversity Protection

[11] National Strategy for Biodiversity Protection

[12] NATURA 2000 Bulgaria http://www.natura2000bg.org/

[13] Protected Areas Act of the Republic of Bulgaria

[14] Rhodope - Common approaches to a joint planning for the promotion of ecologically sensitive sites on the Rhodope mountain http://www.ekby.gr/Rhodope/en/rodopi.htm

[15] Soils Act of the Republic of Bulgaria

[16] Waste Management Act of the Republic of Bulgaria

[17] Water Act of the Republic of Bulgaria

[18] Narŭchnik s preporŭki za opazvane na biologichnoto raznoobrazie v Tsentralnite Rodopi (rid Mursalitsa), Sdruzhenie "Razvitie XXI vek" (Handbook with recommendations for biodiversity preservation in Central Rhodopes (Mursalitsa Hill), XXI century Development Association) 